New Perspectives in the Professional Competence Formation of the Primary Education Teacher

Nicoleta Meseșan 


\title{
New Perspectives in the Professional Competence Formation of the Primary Education Teacher
}

\author{
Nicoleta Meseșan ${ }^{\text {a* }}$ \\ a Doctoral School „Educational, Reflection, Development”, Babes-Bolyai University, 7 Sindicatelor Street, 400029, Cluj-Napoca, Romania \\ *Corresponding author: nicoletamese@yahoo.com
}

Abstract

Keywords: professional competence of the teacher, areas of competence, professional training
Changes in contemporary society demand modifications, adaptations in education. Therefore, by implication, the teaching profession needs reconfigurations to meet the demands of any modern society. The teachers are the ones preparing the next generations of students for efficient professional integration and complex personal development; hence the teaching profession must be in a permanent dynamic. This profession has a certain specificity and a very strong social impact, which is why it requires a number of different specific competences. Due to the complexity of the teaching profession, it was very difficult to structure and summarize the competences that define this field of activity. Regardless of the age level they are addressed to, the professional competences of the teaching staff must be well trained and developed. The social and professional evolution of each student depends on the quality of the educational action. The diversification of the areas of competence in the didactic profession is a must in order to reach a high-quality level in the didactic activity. In this study, areas of competence from the perspective of professionalization of the professional competence of the teacher, but also recent studies that add new skills to this professional field, required by the current society, shall be presented. Thus, primary education teachers, and not only, must be under continuous training.
Schlüsselworte: fachliche Kompetenz des Lehrers, Kompetenzbereiche, professionelles Training
Veränderungen in der heutigen Gesellschaft erfordern Veränderungen, Anpassungen im Erziehungswesen. Das bedeutet dass der Lehrerberuf neu konfiguriert werden muss, um den Anforderungen einer modernen Gesellschaft gerecht zu werden. Die Lehrer sind diejenigen die die nächsten Generationen von Schülern auf eine effiziente berufliche Integration und eine komplexe persönliche Entwicklung vorbereiten. Daher muss der Lehrerberuf in einer permanenten Dynamik sein. Dieser Beruf hat eine gewisse Besonderheit und einen sehr starken Einfluss auf sozialer Ebene, weshalb er eine Reihe verschiedener spezifischer Kompetenzen erfordert. Aufgrund der Komplexität des Lehrerberufs war es sehr schwierig, die Kompetenzen, die diesen Tätigkeitsbreich definieren, zu strukturieren und zusammenzufassen. Unabhängig von der Altersstufe der unterrichteten Schüler müssen die beruflichen Kompetenzen der Lehrkräfte gut ausgebildet und weiterentwickelt werden. Von der Qualität der Bildungsmaßnahmen hängt die soziale und berufliche Entwicklung eines jeden Schülers ab. Um ein hohes Qualitätsniveau in der didaktischen Tätigkeit zu erreichen, ist die Diversifizierung der Kompetenzbereiche im didaktischen Beruf unabdingbar. In der vorliegenden Studie werden Kompetenzbereiche aus der Perspektive der Professionalisierung der beruflichen Kompetenz des Lehrers vorgestellt, und ebenfalls neuere Studien, die diesem Berufsfeld neue Kompetenzen verleihen, die von der heutigen Gesellschaft geforderten sind. Daher müssen die Grundschullehrer und Lehrer allgemein ständig weitergebildet werden.

\section{Conceptual delimitations}

Being a teacher is an expression that designates more than the carrying out of an activity, which is why it is difficult to define precisely the area of competence, the limits and the borders of this profession. The influence of a teacher's personality over the educated extends beyond the classes or the schooling period. This is precisely why is intended to specify very accurately the roles of a teacher. It is often considered that in order to be a good teacher, is sufficient to master the scientific field or to love children, to be pedagogically talented or possess didactic skills, if the reference point is the definition of the teaching profession from the perspective of art. All the aspects listed are important in the delimitation of the competence of the teacher, but they are not sufficient when assessed separately. Their combination is essential in achieving any quality instructional-educational activity. In order to professionalize the didactic activity, it is necessary to establish the coordinates that guide, delimit or orient the field of activity, of competence of the teacher. This is important from several perspectives: that of the teacher to know the expectations of the society from the teaching profession and the personality type of the teacher; from the perspective of the educational institutions that prepare the future teachers, ensuring the 
basic training, in order to carry out a quality training, in line with the areas of competence required by the future activity; and from the perspective of the direct and indirect beneficiaries of the education - students, parents - they shall know the areas of competence of this profession.

\section{National contributions}

In the specialized works, the delimitation of the professional competence of the teacher is achieved according to different criteria: some emphasize, in the description of the profession, on knowledge, skills, abilities from the perspective of the didactic mastery, other papers specify exactly the areas in which a teacher should perform. There are two guidelines in defining the teaching profession: is the teaching profession an art or a science? It must be both art and science as it is founded on scientific basis, but the successful practice of this profession involves the skillful combination of the scientific elements with personality traits to shape the profile of a successful teacher.

\section{$>$ Emil Păun}

Competence is seen as a matrix in which the elements function in full, at the same time, in a prototype situation (Păun, 2017, p. 177). The competence, viewed from this perspective, of a matrix, is standardized through assessment scales that describe the training profile of the teachers. Competence is sometimes interpreted as excellence in a field, thus differentiating a person who shows high competence in a certain area from another who does not possess that competence. Starting from these theoretical arguments, the mentioned paper presents the specific elements of the didactic professional competence: competences in the field of specialty, methodological competences, communication skills, competences of students assessment, competences in the field of knowledge, counseling and guidance of students, skills in management of the class, skills in the field of institutional development, career management skills (Păun, 2017).

\section{$>$ Dan Potolea and Steliana Toma}

The delimitation and grouping of the areas of competence in the teaching profession can be found in the document presented at the Education Congress, prepared by Dan Potolea and Steliana Toma (Bucharest, 2013). Thus, three major categories of competences for the teaching profession are mentioned: specialized skills, professional skills, transversal skills, the composition of each field being presented explicitly.

\section{Knowledge:}

1. Knowledge, understanding of the basic concepts, theories and methods of the field and area of specialization; their proper use in professional communication;

2. Make use of basic knowledge to explain and interpret various types of concepts, situations, processes, projects, etc. associated with the field.

\section{Skills:}

3. Apply basic principles and methods for solving well-defined problem/situations, typical for the field, under qualified assistance;

4. Appropriate use of standard criteria and methods of assessment to assess the quality, merits and limits of processes, programs, projects, concepts, methods and theories;

5. Develop professional projects with the use of established principles and methods in the field.

Professional skills refer to: the design of the didactic activity, the management and monitoring of the learning process, the assessment of the educational activities, the use of digital technologies, the knowledge, counseling and differentiated treatment of the students and the management of the classroom.

Transversal skills include: institutional development of school and school-community partnership, career management and personal development, applied educational research.

\section{European and international studies}

At European level, competences are presented analytically, establishing professional standards for each competence (European Commission, 2013 https://ec.europa.eu/assets/eac/education/policy/school/ doc/teachercomp_en.pdf). Competence includes: knowledge, skills and attitudes. The professional competences of the teacher are presented comparatively, aiming specific aspects of countries from the EU area. Such an approach is achieved in order to harmonize the initial training of teachers to be recognized in the European community. "The knowledge, skills and attitudes of teachers, as well as their quality in the field of school management, are the most important factors in 
obtaining high quality educational results" (http://ec.europa.eu/education/policy/school/teachingprofessions_en).

Teachers need to be very well trained in their area of expertise, possess the pedagogical skills necessary to pass on the specialized knowledge to students, to be able to teach in heterogeneous classes, effectively use ICT and help students build their transversal skills. For example, for the basic training carried out in Romania, the description is as follows: "The teacher for primary education/the schoolmaster teaches almost all the subjects in the curriculum to the students in the age group 6-10 years. They organize the classroom and learning resources and encourage the framework for positive learning. The teacher plans, prepares and teaches lessons that feed the needs of the whole class. Develops assessment tools, evaluates school results and records students' progress. He/ she works with parents to maximize their involvement and resource development in school"

(http://ec.europa.eu/growth/toolsdatabases/regprof/index .cfm?action=regprof\&id_regprof=30654).

The competences of any person can be defined according to the knowledge, skills and behavior of that person. In order to understand the competences required of a teacher, the workplace of a teacher must first be defined. The duty of a teacher is closely linked to the nature of the class, the structure and characteristics of the learner group. Today's classes require teachers to "prepare virtually all students for higher order thinking and performance skills" (Darling-Hammond, 2006, p. 300), this being pursued, sometimes, only for a few students.

Researchers and practitioners are becoming increasingly aware that the needs of 21 st century learner groups and, therefore, the requirements for both students and teachers are undergoing significant changes. Today's teachers need to develop a holistic range of skills: for teaching and learning, administration and management, as well as knowledge in various fields: about themselves and learners, about community and pedagogy, among many others. What are the roles of the teacher in the $21 \mathrm{st}$ century? What are the skills that teachers must possess to fulfill these roles? A team of teachers from the National Institute of Education in Singapore (http://singteach.nie.edu.sg/issue23-teachered/) listed some of the roles that any member of the teaching staff must perform. Some of the roles identified are:
- Care for the development of the child as a whole;

- Providing quality learning activities;

- Collaboration with other persons specialized in education, but also in other fields;

- Developing a strong set of personal values.

The research mentioned specifies the set of basic competences that any teacher should possess in order to fulfill these roles. These competences have been classified into three dimensions of performance (http://singteach.nie.edu.sg/issue23-teachered/):

- Professional practice;

- Leadership and management;

- Personal effectiveness.

\subsection{Professional practice}

In carrying out the didactic activity, any competent teacher uses every opportunity to encourage learning, always assuming that all students have the ability to learn. Learning is not just limited to the classroom. To this end, the teacher must take every opportunity to improve his/her professional practice and to provide quality learning, in non-formal or even informal education.

\subsection{Leadership and management}

Any competent teacher wins the hearts and minds of students, being a leader of the class of students. Such a teacher is aware of the need for professional evolution and development by collaborating with others, including the students' parents, and is actively seeking professional training opportunities both within and outside the school.

\subsection{Personal efficiency}

Any good teacher is aware of the importance of personal development. From this perspective, the teacher maintains high standards of personal and professional integrity when he/ she fulfills his/ her duties and responsibilities.

\section{New perspectives in the professional competence of the member of the teaching staff}

In a period of major political, social, demographic changes at European and global level, education is adapting and gearing to meet the demands of today's society. New perspectives are therefore opening in the training of future primary education teachers. 


\subsection{Global competence}

Education for multiculturalism and diversity viewed from the perspective of interdisciplinary education, of an integrated curriculum, implies the extension and adaptation of professional competences. This is how one can speak of global competence (http://www.nafsa.org/).

How does global competence look like in a teacher? Some coordinates are presented below (Soppelsa, Manise, 2015):

1. Understanding one's own cultural identity and its influence on the classroom practice;

2. Knowing and integrating global dimensions within the subjects one teaches;

3. Engaging students in learning about the world and in exploring their place in it worldwide;

4. Using real-life global examples, materials, and resources when considering local, national, and human issues;

5. Valuing the input of culturally and linguistically diverse learners, families, and colleagues, and modeling cultural sensitivity;

6. Creating environments that encourage positive cross-cultural interaction;

7. Modeling social responsibility in local and global contexts;

8. Helping learners find appropriate actions to improve local and global conditions;

9. Assessing learners' global competence and providing growth opportunities;

10. Advocating for global education and social responsibility.

Together, these and related elements led to the development of this definition of global competence for teachers. According to NAFSA: Association of International Educators: "Global competence in teachers is a set of essential knowledge, critical dispositions, and performances that help foster development of learners' global competence. A globally competent teacher has knowledge of the world, critical global issues, their local impact, and the cultural backgrounds of learners, manifests intercultural sensitivity and acceptance of difference, incorporates this knowledge and sensitivity into classroom practice, and develops the skills to foster these dispositions, knowledge, and performances in learners. The teacher shapes socially responsible action and creates opportunities for learners to engage in socially responsible action" (ㄷ) NAFSA: Association of
International

Educators,

2015

http://blogs.edweek.org/edweek/global_learning/2015/08 /the_top_10_characteristics_of_globally_competent_teac hers.html).

Global competence for teachers is no longer for just an elite few, but rather is an essential element of preparation for all teachers. It is necessary to form this competence whilst preparing tomorrow's teachers.

\subsection{The ability to adapt to new}

In the modern, digital age, a teacher needs to be flexible and adaptable. Modern teachers know how to cope with challenges without fear. The digital age can be called the era of change. New technologies and educational strategies are introduced every minute. Each student learns in a different way and at a different pace. The guidelines and expectations in education are constantly updated and revised. The adaptation to the new implies both the introduction of new technologies in learning and the knowledge and application of new learning strategies.

4.2.1. Flipped classroom is a combined learning strategy, applied in order to improve the involvement of students in learning and their results. This concept can be assimilated with pedagogies such as: active learning, peer-to-peer training, case-based or problem-based learning, or any combination of learning strategy that asks students to prepare the learning/topic before meeting and to engage with colleagues in learning activities (https://sydney.edu.au/education-

portfolio/ei/news/pdfs/flipped-classrooms.pdf). The basis of this strategy is the use of digital educational resources, especially of the Internet, and the teacher has the role of coordinator of the learning activity, thus exceeding the traditional model of the teacher as sole treasurer of knowledge (Jenkins, 2017).

4.2.2. Agile learning is a learning strategy based on the dynamic planning of the learner's activities, on the ability to make decisions, to raise awareness of the needs and to prioritize the learning activities. Many learning settings require dynamic (agile) planning for both the teacher and his/ her students (Briggs, 2014).

4.2.3. Visible learning is an integrating concept that includes effective teaching and learning strategies. When teaching and learning are visible, "there is a high probability that students will achieve high levels of learning success" (Hattie, 2014). The teacher has the role 
of an expert who "masters a series of training strategies to build the surface and depth knowledge of the students and to understand the meaning of the content and understanding" (ibidem). The teacher must know when to withdraw: "when the learning takes place and when the learner's progresses towards the desired educational performance" (ibid.).

4.2.4. A primary school teacher should help students cope with change, i.e. to help children adapt. In a study of the University of Sydney on the effects of adaptability on the evolution of young people, it was found that the effects of adaptability are very strong, and adaptability is a factor with a high impact on academic and nonacademic outcomes (Martin, 2013). In order to help students to adapt, for the purpose of increased school performance and complex and comprehensive personal development, the teacher himself/ herself must prove this ability: to cope with change.

\subsection{Work skills with students with special needs}

The school and professional integration of students with special needs are important requirements of the contemporary society. Starting from this goal, the competences of the teacher for primary education need to be rethought and diversified to meet the need for integrated education and school inclusion. Inclusive education aims at developing positive interpersonal relationships, adapting school curricula according to the needs of students with special educational needs (SEN), diversifying educational actions and strategies for students with SEN, ensuring equal access to education, specific learning situations and activities (Gherguț, 2016). Inclusive education refers to all students, to educational and developmental needs, and starts from the idea that in different development periods, every child has special needs. Thus, the child is at the core of attention as a complete universe and as a partner in education (Vrăşmaş, 2005). Students with ADHD, with autism spectrum disorders, sensory or motor impairments, learning difficulties are often included in mainstream education. Thus, the primary education teacher must have specific skills for this type of education. These competences could be described by: knowing the specificity of the problem of the student's/ students' with special needs within the student group, adapting the teaching strategies within the teaching activity to the learning needs of the students, fostering an environment conducive to the relationship between the students of the classroom and between parents of children in the classroom (Gherguț, 2016), cooperation with the itinerant teacher, the school psychologist and the student's family for curricular adaptation, differentiated evaluation, progress monitoring and, possibly, reorganization of the teaching strategy. Thus, the primary education teacher must capitalize on the positive aspects of the students' personality in order to help, coordinate and guide them in an efficient learning process.

\subsection{ICT skills for teaching, new technologies at the workplace}

ICT competences can be included in the category of transversal didactic competences, but in view of the evolution of new technologies and their use on a larger scale in the educational act, this category of competences is included in the category of professional competences. At European level, the 2012 Euridice report states that almost all countries have a national strategy for digital competence formation in students. This implies ensuring a high level of digital skills among teachers, implicitly among primary education teachers (Competența digitală, o abilitate esențială pentru profesori și elevi în secolul $X X I$, 2017 , https://www.schooleducationgateway.eu/ro/pub/resource s/tutorials/digital-competence-the-vital-.html).

The inclusion of ICT in the teaching-learning activity has relevant training strengths: students are actively learning, learning using the computer or tablet is a learning based on exploration, the information resources are at hand, being accessible, and this increases the motivation of learning and fosters deep learning. The emphasis is on learning as a process, not just on the product, thus managing to train students certain skills of: communication, collaboration, involvement, critical thinking (Wojcicki, Education Talks). These skills are needed in any field of activity, so it is important to train students starting at the elementary level, using technology in the teaching-learning activity facilitating this aspect. As stated, the training of digital skills should start from an early age, but the teachers are the ones who decide on the optimal ways in which this competence shall be formed, the type of technology used as well as the time allocated to digital activities. For students to gain and to develop digital skills, an important condition is to ensure a high level of digital competence among teachers. 


\subsection{Skills for tailored learning strategies and building interdisciplinary skills in students}

Approaching learning from new perspectives, in order to meet the new demands of the modern learner and, implicitly, of the society, demands for a new category of skills: from being able to design and use differentiated teaching-learning strategies to individualization, as they will help students to establish an independent learning style as a starting point in the formation of the long-life learning competence. Students enter the training field with a different set of information, with different perspectives, expectations and needs, with their own life experience, with a specific way of thinking and learning ability (Pânişoară, 2015). In this situation, the solution for optimal learning outcomes is differentiated instruction, the teacher's teaching style being modeled on what a student can effectively achieve. For this purpose, the teacher must acquire in the initial and continuous training, skills for individualized learning strategies.

An integrated curriculum, based on interdisciplinarity, aims to train interdisciplinary skills in learners by: transposing new information into concrete life situations, making connections between information acquired in different subjects, building a holistic cognitive system, critical thinking, divergent, reflective thinking, and this task rests with the teacher.

\section{Conclusions}

The member of the primary education teaching staff must develop competences in specific teaching strategies that lead to the formation of interdisciplinary skills in students. Consequently, the integrated design of the contents, the design, organization and achievement of the learning activities in an interdisciplinary way, the fostering of the learning strategies based on the project, on the learning by discovery or the learning based on the solution of problems are some areas of competence for the teaching staff, that must be valorized in school practice to lead to the formation of interdisciplinary skills in primary school students.

The primary education teacher's ability to adapt to new requires time and availability to assimilate the innovative aspects of society and, implicitly, of education.
Teachers are recommended, but also have the concurrent obligation to update their information in the professional field, to be up to date with the news in the field. Moreover, their priority objective should be continuous personal growth and professional excellence acquired through life-long learning.

\section{Authors note:}

Nicoleta Meseșan is Ph.D. Student, Faculty of Psychology and Education Sciences, Babeș-Bolyai University.

\section{References}

Briggs, S. (2014). Agile Based Learning: What Is It and How Can It Change Education? (2014). Available at: https://www.opencolleges.edu.au/informed/features/agilebased-learning-what-is-it-and-how-can-it-change-education/ (accessed at 25.06.2019).

Darling-Hammond, L. (2006). Constructing 21st-century teacher education Journal of Teacher Education, Vol. 57, No. 3, May/June 2006 300-314 DOI: 10.1177/0022487105285962. Available at:

http://citeseerx.ist.psu.edu/viewdoc/download?doi=10.1.1.83 $2.9275 \&$ rep $=$ rep $1 \&$ type $=$ pdf $($ accessed at 03.04 .2019$)$.

Gherguț, A. (2016). Educația incluzivă și pedagogia diversităţii. Iaşi: Polirom.

Hattie, J. (2014). Invățarea vizibilă - ghid pentru profesori. Bucureşti: Editura Trei.

Jennings, P.A. (2017). Mindfulness pentru profesori. Bucureşti: Editura Herald.

Martin, A. (2013). Coping with change: teaching adaptability will help kids grow, november 10, 2013. Available at: $\mathrm{https}$ ://theconversation.com/coping-with-change-teachingadaptability-will-help-kids-grow-19726, (accessed at 05.04.2019).

Pânișoară, I.-O. (2015). Profesorul de succes. 59 de pincipii de pedagogie practică. Iași: Polirom.

Păun, E. (2017). Pedagogie. Provocări și dileme privind școala și profesia didactică. Iaşi: Polirom.

Potolea, D., Toma, S. (2013). Standarde pentru profesia didactică. Congresul Educației, 13-14 Iunie 2013, Bucureşti. Available

http://www congresuleducatiei.ro/ckfinder/userfiles/files/ST oma \%20DPotolea.pdf (accessed at 25.02.2018).

Soppelsa, B., Manise, J. (2015). The Top 10 Characteristics of Globally Competent Teachers. Available at: http://blogs.edweek.org/edweek/global_learning/2015/08/the _top_10_characteristics_of_globally_competent_teachers.ht $\overline{\mathrm{ml}}$ (accessed at 25.04.2019).

Vrășmaș E., Educația copiilor cu cerinţe educative speciale Proiectul pentru învățământ rural - Curs pentru învățământ la distanță. Available at: https://www.academia.edu/20088566/69139698-ModululEd-Copiilor-Cu-CES (accessed at 23.11.2019).

Wojcicki, E., Education Talks/Digital revolution in the classroom. Available 
https://www.youtube.com/watch?v=c6uT1hO6QEQ (accessed at 10.11.2019).

*** Competența digitală, o abilitate esențială pentru profesori şi elevi în secolul XXI (2017). Available at: https://www.schooleducationgateway.eu/ro/pub/resources/tu torials/digital-competence-the-vital-.html (accessed at 08.10.2019).

*** Flipped Classes. Available at: https://sydney.edu.au/educationportfolio/ei/news/pdfs/flipped-classrooms.pdf (accessed at 03.09.2019).

*** Supporting teacher competence development for better learning outcomes, European Commission (2013). Available at: https://ec.europa.eu/assets/eac/education/policy/school/doc/t eachercomp_en.pdf (accessed at 23.10.2019).

*** The Competent Teacher (sign.teach.nie.edu.sg), Issue 23 Mar/ Apr 2010. Available at: https://singteach.nie.edu.sg/wpcontent/uploads/SingTeach_Issue23.pdf. (accessed at 25.09.2019).

https://ec.europa.eu/education/policies/school/teaching$\% 20 \% 20$ professions_en (accessed at 15.07.2019). http://ec.europa.eu/growth/toolsdatabases/regprof/index.cfm?a ction=regprof\&id_regprof=30654. (accessed at 15.09.2019). https://www.schooleducationgateway.eu/ro/pub/resources/tuto rials/digital-competence-the-vital-html (accessed at 25.09.2019).

http://www.nafsa.org (accessed at 16.08.2019). 